\title{
Preliminary Study on Physico-Chemical Parameters and Phytoplankton of Chiffa River (Blida, Algeria)
}

\author{
Fella Hamaidi-Chergui, ${ }^{1}$ Mohamed Brahim Errahmani, ${ }^{2}$ \\ Fatouma Benouaklil, ${ }^{1}$ and Mohand Said Hamaidi ${ }^{1}$ \\ ${ }^{1}$ Department of Biology, University Saâd Dahlab, BP 270, Route de Soumaa, Blida, Algeria \\ ${ }^{2}$ Department of Chemistry, University Saâd Dahlab, BP 270, Route de Soumaa, Blida, Algeria \\ Correspondence should be addressed to Fella Hamaidi-Chergui; hamaidifella@yahoo.fr
}

Received 20 November 2012; Revised 19 January 2013; Accepted 18 February 2013

Academic Editor: Fu-Liu Xu

Copyright (C) 2013 Fella Hamaidi-Chergui et al. This is an open access article distributed under the Creative Commons Attribution License, which permits unrestricted use, distribution, and reproduction in any medium, provided the original work is properly cited.

\begin{abstract}
The present study was carried out to determine the monthly variations of physico-chemical parameters in water samples from Chiffa river at Blida, North West of Algeria from April to August 2006. Water samples were analyzed for physico-chemical parameters and the results showed their monthly variations as follows: $\mathrm{pH} 7.5-7.6$, electrical conductivity $0.87-1.06 \mathrm{mS} \cdot \mathrm{cm}^{-1}$, nitrate $0-7.00 \mathrm{mg} \cdot \mathrm{L}^{-1}$, nitrite $0-0.28 \mathrm{mg} \cdot \mathrm{L}^{-1}$, ammonia $0-0.03 \mathrm{mg} \cdot \mathrm{L}^{-1}$, phosphate $0-0.94 \mathrm{mg} \cdot \mathrm{L}^{-1}$, sodium $19.3-47.0 \mathrm{mg} \cdot \mathrm{L}^{-1}$, chloride $35.7-52.0 \mathrm{mg} \cdot \mathrm{L}^{-1}$, calcium $90.3-104.7 \mathrm{mg} \cdot \mathrm{L}^{-1}$, magnesium $27.3-37.7 \mathrm{mg} \cdot \mathrm{L}^{-1}$, organic matter $0.4-3.9 \mathrm{mg} \cdot \mathrm{L}^{-1}$, chlorophyll a $0.7-132.3 \mathrm{mg} \cdot \mathrm{L}^{-1}$, and bicarbonate $219.3-248.7 \mathrm{mg} \cdot \mathrm{L}^{-1}$. The analyzed physico-chemical parameters were almost not exceeded the maximum permissible limit of WHO and Algerian Water Quality Guidelines. A total of 53 taxa belonging to 4 divisions have been identified, including Chlorophyta (52.83\% of taxa), Bacillariophyta (28.30\%), Cyanophyceae (16.98\%), and Charophyta (1.89\%).
\end{abstract}

\section{Introduction}

Aquatic ecosystems are particularly vulnerable to environmental change and many are, at present, severely degraded [1]. The availability of good quality water is an indispensable feature for preventing disease and improving quality of life. The physico-chemical properties will also help in the identification of sources of pollution, for conducting further investigations on the ecobiological impacts and also for initiating necessary steps for remedial actions in case of polluted water bodies $[2,3]$. Therefore, the nature and health of any aquatic community are an expression of quality of the water. In recent years, increase in human population, demand for food, land conversion, and use of fertilizer have led to faster degradation of many freshwater resources $[4,5]$. The discharge of urban, industrial, and agricultural wastes has added the quantum of various harmful chemicals to the water body considerably altering their inherent physicochemical characteristics [6]. The monitoring of quality of such surface waters by estimating hydrobiological parameters is among the major environmental priorities as it permits direct assessment of the status of ecosystems that are exposed to deleterious anthropogenic factors [7]. The alteration in physico-chemical parameters leading to eutrophication has become a widely recognized problem of water quality deterioration [5].

Phytoplankton constitutes the basic components of the aquatic food chain. They act as primary producers and represent themselves as a direct food source for other aquatic animals.

The interplay of physical, chemical, and biological properties of water most often leads to the production of phytoplankton, while their assemblage (composition, distribution, diversity, and abundance) is also structured by these factors.

The literature on freshwater algae in Algeria is scarce and limited to a few areas. Vast areas remain unexplored. In addition, the extreme diversity of aquatic ecosystems necessitates a constant knowledge of freshwater algae. However, the work of Gauthier-Lievre [8] and Baudrimont [9] should be mentioned. More recently, works of Bensouilah et al. [10], 


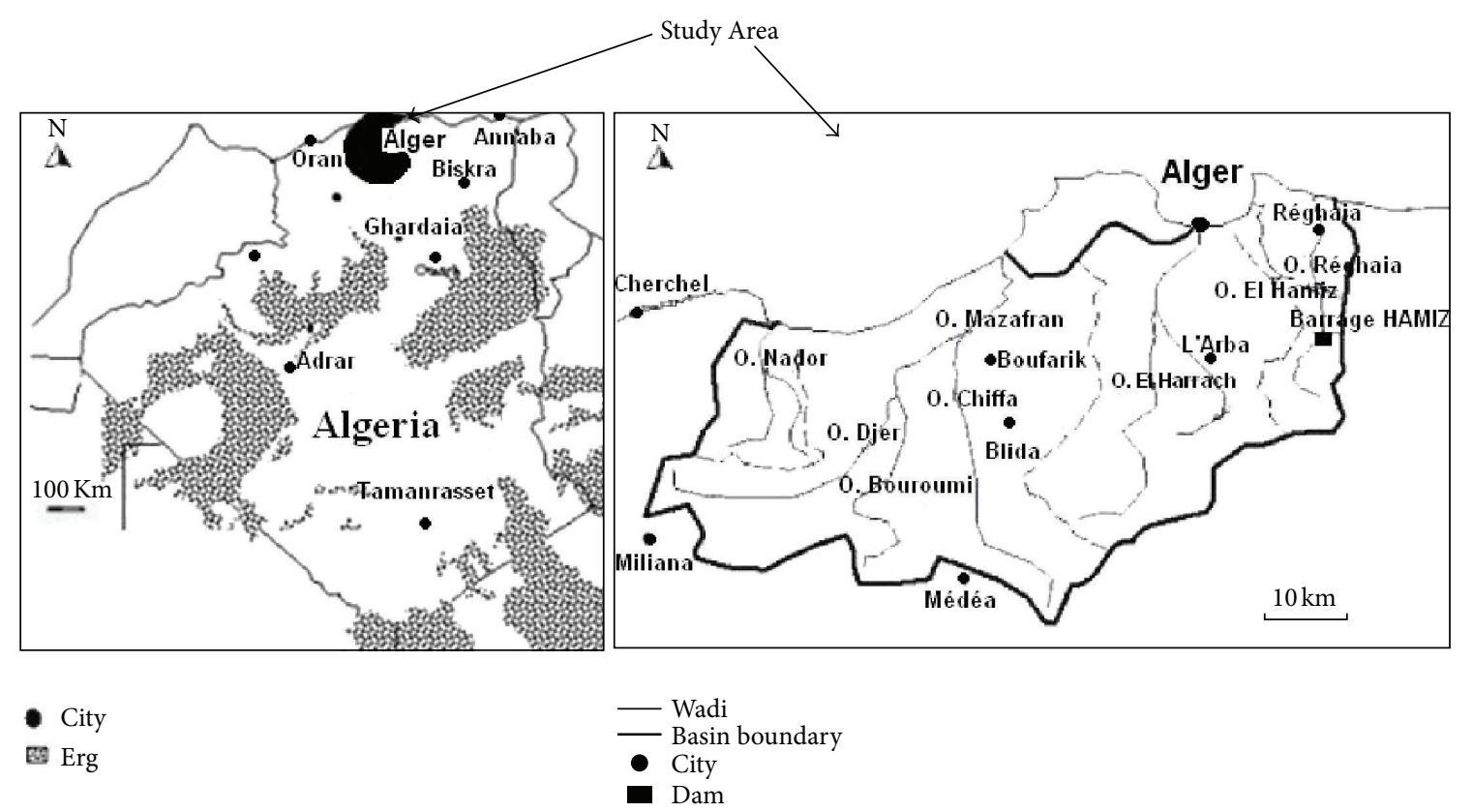

Figure 1: Study site [24].

Nasri et al. [11-14], Soumati et al. [15], Souissi et al. [16], Amri et al. [17] and Ouartsi et al. [18] were interested mainly in Cyanophyceae in the North East of Algeria (Lake Oubeira). Other studies relate to populations of phytoplankton of the river Cheliff [19], Lake Oubeira by Branes et al. [20] or Diatomophyceae of river Kabir [21], and phytoplankton from Ghrib dam [22].

The literature reveals that there is no scientific study carried out with respect to ecological characteristics of Chiffa river, and the main objective of this work has to analyze various physico-chemical parameters and to examine the phytoplankton from April to August 2006.

\section{Materials and Methods}

2.1. Study Area. Chiffa river is located in the north-western part of Algeria (Figure 1); it originates in the Medea Mountains and sinks to the bottom of the gorge of Chiffa, in the Blidean Atlas between the Blida massive and the Mouzaia massive. With a length of $35 \mathrm{~km}$, it is one of the main tributaries to Mazafran river [23].

2.2. Analysis of Water. The surface water samples were collected from three points, namely, S1, S2, and S3 (Figure 2) between 8 and 10 a.m. from April to August 2006. Though the three stations were selected for sampling, average values of samples are taken for each parameter studied.

To collect water samples, cleaned and rinsed plastic containers of two-liter capacity were used. Water samples were tested for different physico-chemical parameters. The chemical parameters as $\mathrm{pH}$ and temperature were measured in the field using a $\mathrm{pH}$ meter. Conductivity of water was measured in the field by a conductivity meter. Nitrate,

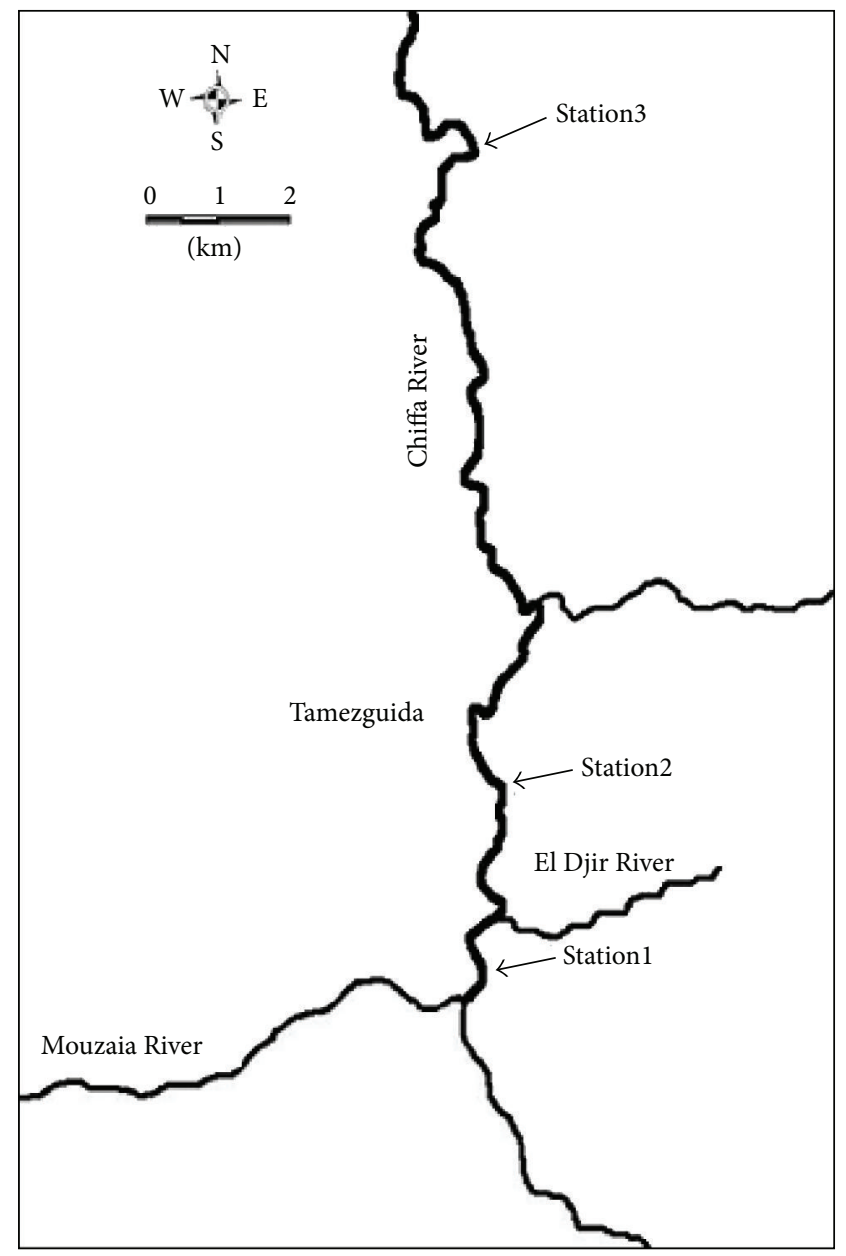

FIGURE 2: Sampling sites. 
TABLE 1: Monthly variations of mean values of physico-chemical parameters in Chiffa river.

\begin{tabular}{|c|c|c|c|c|c|c|c|}
\hline Parameters & April & May & June & July & August & Algerian guidelines & WHO Standards \\
\hline$T\left({ }^{\circ} \mathrm{C}\right)$ & 15.0 & 20.7 & 19.3 & 22.7 & 22.7 & 30 & $25-30$ \\
\hline $\mathrm{pH}$ & 7.6 & 7.6 & 7.6 & 7.5 & 7.6 & $6.5-8.5$ & $6.5-8.5$ \\
\hline $\mathrm{EC}\left(\mathrm{mS} \cdot \mathrm{cm}^{-1}\right)$ & 1.00 & 0.90 & 1.03 & 0.87 & 1.06 & 2800 & $180-1000$ \\
\hline $\mathrm{NO}_{3}{ }^{-}\left(\mathrm{mg} \cdot \mathrm{L}^{-1}\right)$ & 3.00 & 0.67 & 7.00 & 0.00 & 0.00 & 50 & 50 \\
\hline $\mathrm{NO}_{2}^{-}\left(\mathrm{mg} \cdot \mathrm{L}^{-1}\right)$ & 0.28 & 0.00 & 0.00 & 0.00 & 0.00 & 0.1 & $\leq 0.1$ \\
\hline $\mathrm{NH}_{4}^{+}\left(\mathrm{mg} \cdot \mathrm{L}^{-1}\right)$ & 0.00 & 0.03 & 0.00 & 0.00 & 0.00 & 0.5 & $\leq 0.1$ \\
\hline $\mathrm{PO}_{4}{ }^{3-}\left(\mathrm{mg} \cdot \mathrm{L}^{-1}\right)$ & 0.06 & 0.94 & 0.14 & 0.01 & 0.00 & 0.5 & 0.2 \\
\hline $\mathrm{Na}^{+}\left(\mathrm{mg} \cdot \mathrm{L}^{-1}\right)$ & 47.00 & 19.33 & 41.33 & 43.67 & 44.33 & 100 & 150 \\
\hline $\mathrm{Cl}^{-}\left(\mathrm{mg} \cdot \mathrm{L}^{-1}\right)$ & 46.67 & 35.67 & 52.00 & 48.00 & 47.33 & 250 & 250 \\
\hline $\mathrm{Ca}^{2+}\left(\mathrm{mg} \cdot \mathrm{L}^{-1}\right)$ & 101.67 & 83.33 & 104.67 & 90.33 & 92.00 & 75 & 200 \\
\hline $\mathrm{Mg}^{2+}\left(\mathrm{mg} \cdot \mathrm{L}^{-1}\right)$ & 34.67 & 37.67 & 31.00 & 27.33 & 30.33 & 50 & 50 \\
\hline Org. m. (mg. $\left.\mathrm{L}^{-1}\right)$ & 3.93 & 1.13 & 0.40 & 1.43 & 1.23 & & $<5$ \\
\hline Chl.a $\left(\mu \mathrm{g} \cdot \mathrm{L}^{-1}\right)$ & 0.70 & 1.87 & 9.95 & 132.3 & 85.56 & & \\
\hline $\mathrm{HCO}_{3}{ }^{-}\left(\mathrm{mg} \cdot \mathrm{L}^{-1}\right)$ & 242.7 & 248.7 & 224.7 & 219.7 & 219.3 & 200 & \\
\hline
\end{tabular}

Temp: temperature; EC: electrical conductivity; $\mathrm{NO}_{3}{ }^{-}$: nitrate; $\mathrm{NO}_{2}{ }^{-}$: nitrite; $\mathrm{NH}_{4}{ }^{+}$: Ammoniac; $\mathrm{PO}_{4}{ }^{3-}$ : Phosphate; $\mathrm{Na}^{+}$: Sodium; $\mathrm{Cl}^{-}: \mathrm{Chloride} \mathrm{Ca}^{2+}$ : Calcium; $\mathrm{Mg}^{2+}$ : Magnesium; Org m.: organic matter; Chl.a: Chlorophyll a; $\mathrm{HCO}_{3}{ }^{-}$: Bicarbonate.

nitrite, chloride, and phosphate were analyzed according to the standard methods described by $[25,26]$. Samples for cations (calcium, magnesium) were analyzed by atomic absorbance spectrophotometry, while sodium was measured by flame photometry. Bicarbonate was determined by acid titration method. The organic matter was determined by permanganate oxidation method [26]. Subsamples were filtered (Whatman GF/C membranes) and used to quantify chlorophyll-a spectrophotometer, (after acetone extraction) [27].

\subsection{Phytoplankton Collection and Preservation}

2.3.1. Preservation. Phytoplankton samples were collected by using filtering water samples using plankton net (mesh size $105 \mu \mathrm{m}$ ) and preserved in $1000 \mathrm{~mL}$ plastic bottle by adding $5 \mathrm{~mL}$ of $4 \%$ formalin concentration.

The preserved samples were kept for $24 \mathrm{~h}$ undisturbed to allow the sedimentation of plankton suspended in the water. After $24 \mathrm{~h}$, the supernatant was discarded carefully without disturbing the sediments and the final volume of concentrated sample was about $10 \mathrm{~mL}$.

2.3.2. Qualitative and Quantitative Analysis of Phytoplankton. Quantitative analysis of phytoplankton was done by putting one drop of fixed sample $(0.040 \mathrm{~mL})$ on the glass slide and studying it under inverted microscope. The results were obtained by recording the number of organisms per mL. The species were identified under microscope and classification was done with standard works [28-34] and more specific literature.

2.4. Statistical Analysis. Correlations between physicochemical parameters were analyzed using Pearson's correlation. We then compared these physico-chemical parameters among different months using Kruskal-Wallis
ANOVA on ranks or Student's $t$-test for comparison with references. Results are given as mean \pm SE.

\section{Results and Discussion}

3.1. Physico-Chemical Parameters. The results of mean values of physico-chemical parameters are given in Table 1, Figure 3.

The water temperature plays an important role in the solubility of salts and gases. It is one of the most significant parameters which control inborn physical qualities of water. In this study, the water temperature fluctuated between $15.0^{\circ} \mathrm{C}$ and $22.7^{\circ} \mathrm{C}$. The maximal temperatures were recorded in July and August $\left(22.7^{\circ} \mathrm{C}\right)$. The variations in ambient temperature followed a seasonal climatic pattern. The temperatures observed were lower than the Algerian standards; we may recall that temperatures higher than $15^{\circ} \mathrm{C}$ favor the development of microorganisms and activate chemical reactions [35].

The $\mathrm{pH}$ is also a factor which influences the biological activity of the water microflora. The principal component regulating ion $\mathrm{pH}$ in natural waters is the carbonate, which comprises $\mathrm{CO}_{2}, \mathrm{H}_{2} \mathrm{CO}_{3}$, and $\mathrm{HCO}_{3}^{-}$[36]. Low values in $\mathrm{pH}$ are indicative at high acidity, which can be caused by the deposition of acid forming substances in precipitation. A high organic content will tend to decrease the $\mathrm{pH}$ because of the carbonate chemistry. All samples display an average $\mathrm{pH}$ slightly basic $7.6 \pm 0.03$ (range 7.5-7.6), without significant differences $(P=0.74$, annex 1 in Supplementary Material available online on http://dx.doi.org/10.1155/2013/148793). Generally, the obtained values were in agreement with the Algerian and the world health organization standards (6.58.5). A neutral $\mathrm{pH}$ in the interval (6.5-8.5) characterizes water where life develops in optimal way [37].

Conductivity is a good and rapid method to measure the total dissolved ions and is directly related to total solids [38]. The electrical conductivity (EC) of water samples in Chiffa river ranges from 0.87 to $1.06 \mathrm{mS} \cdot \mathrm{cm}^{-1}$, all comparable values 

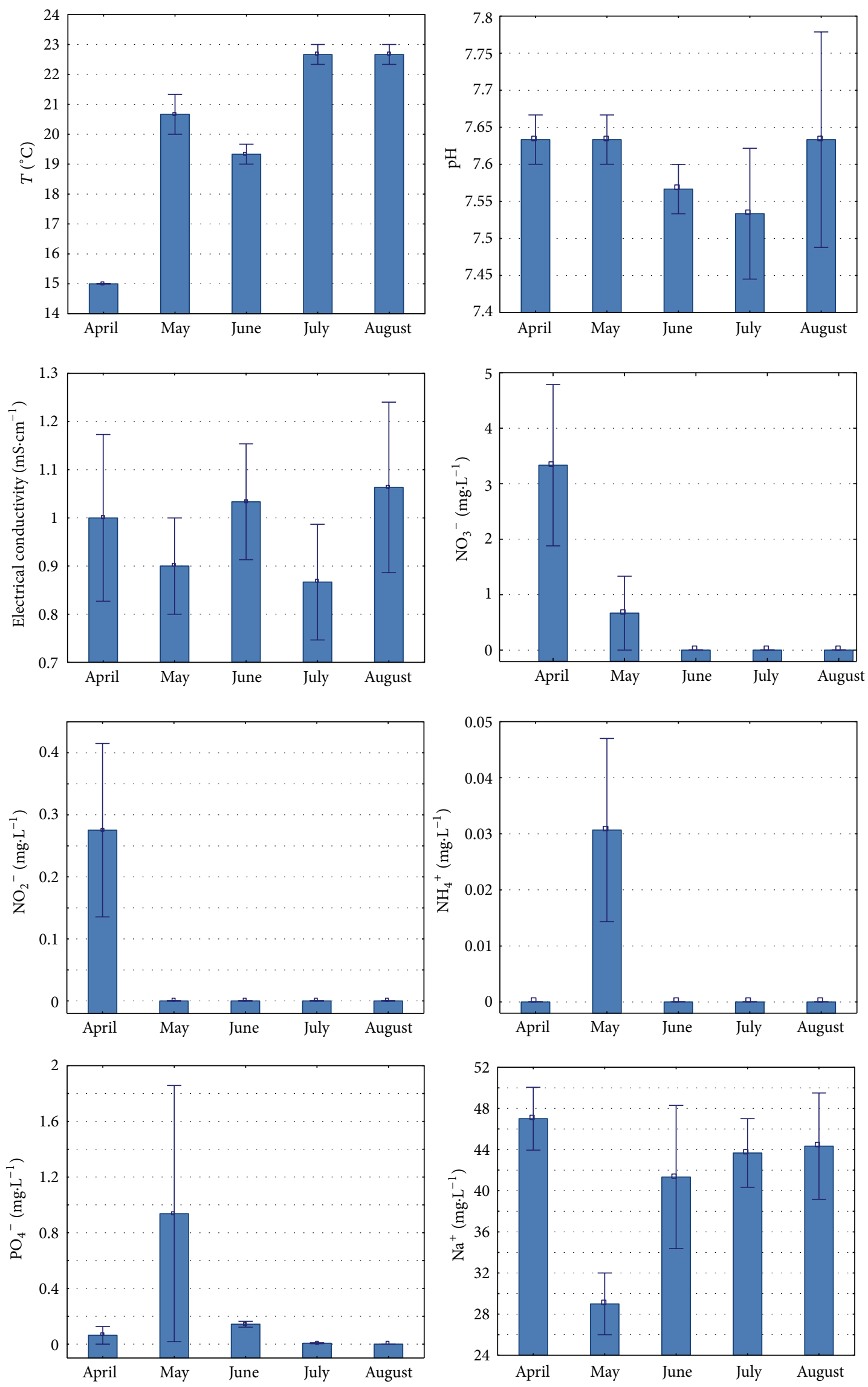

Figure 3: Continued. 

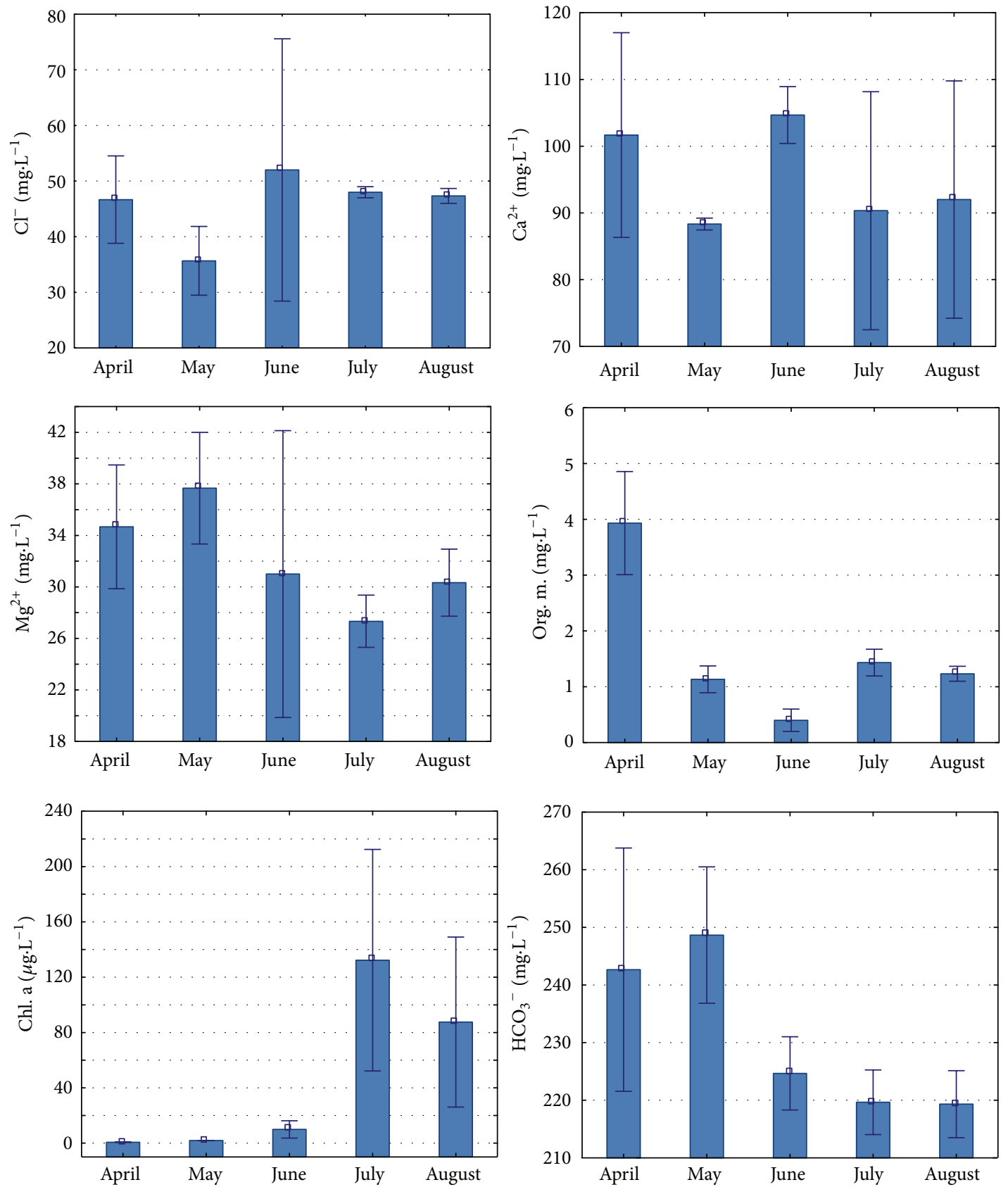

Figure 3: Monthly average values of temperature, $\mathrm{pH}$, electrical conductivity, nitrate, nitrite, ammonium, phosphate, sodium, chloride, calcium, magnesium, organic matter, chlorophyll a, and bicarbonate between April and August 2006 at Chiffa river.

$(P=0.83)$ but with a mean $0.97 \pm 0.06$ very significantly higher than $0.35 \mathrm{mS} \cdot \mathrm{cm}^{-1}(P<0.001)$ which is the average value of typical unpolluted rivers.

Human activities and mainly those related to agriculture are a major cause of the presence of nitrates and nitrites in surface water. These two substances are responsible for many problems not only for environment but also for human health. Indeed, although not directly toxic, they participate in eutrophication phenomena of surface water. We have the nitrate concentration in the range $\left(0-7.00 \mathrm{mg} \cdot \mathrm{L}^{-1}\right)$, the nitrites concentration in the range $\left(0-0.28 \mathrm{mg} \cdot \mathrm{L}^{-1}\right)$, and the ammonium ion concentration in the range $\left(0-0.03 \mathrm{mg} \cdot \mathrm{L}^{-1}\right)$. This allows us to notice that the rates of nitrates obtained are lower than the standards required which are in the order of $50 \mathrm{mg} \cdot \mathrm{L}^{-1}[39,40]$ (Table 1). Their presence can be explained by an incomplete oxidation of the ammonia water or a nitrate reduction reaction. This pollution can be caused by intense agricultural activity (the studied region is known for its agricultural vocation) and misuse of chemical fertilizers around the sewage waste water and Chiffa river. 
TABLE 2: Pearson correlation coefficient and significance level between the physico-chemical variables of Chiffa river at Blida, Algeria.

\begin{tabular}{|c|c|c|c|c|c|c|c|}
\hline & $T$ & $\mathrm{EC}$ & $\mathrm{NO}_{3}{ }^{-}$ & $\mathrm{NO}_{2}^{-}$ & $\mathrm{NH}_{4}^{+}$ & $\mathrm{Na}^{+}$ & $\mathrm{Mg}^{2+}$ \\
\hline $\mathrm{NO}_{3}^{-}$ & $(-)^{* *}$ & & & & & & \\
\hline $\mathrm{NO}_{2}^{-}$ & $(-)^{* *}$ & & $(+)^{* * *}$ & & & & \\
\hline $\mathrm{Na}^{+}$ & & $(+)^{*}$ & & & $(-)^{* * *}$ & & \\
\hline $\mathrm{Cl}^{-}$ & & & & & & $(+)^{*}$ & \\
\hline $\mathrm{Ca}^{2+}$ & & $(+)^{* *}$ & & & & & \\
\hline Org m. & $(-)^{*}$ & & $(+)^{* * *}$ & $(+)^{* * *}$ & & & \\
\hline $\mathrm{HCO}_{3}^{-}$ & & & $(+)^{* *}$ & $(+)^{*}$ & & & $(+)^{*}$ \\
\hline
\end{tabular}

The phosphate value varied from 0 to $0.94 \mathrm{mg} \cdot \mathrm{L}^{-1}$. The highest concentration of phosphate was noted in the month of May with lowest value during July and August. The main environmental impact associated with phosphate pollution is eutrophication. The US Environmental Protection Agency [41] suggested that $0.08 \mathrm{ppm}$ of phosphate is the critical level for the occurrence of eutrophication in lakes and reservoirs.

Ohle [42] classified the water bodies into three categories on the basis of calcium richness: (i) poor, (ii) medium, and (iii) rich. The mean value of calcium $\left(\mathrm{Ca}^{2+}\right)$ and magnesium $\left(\mathrm{Mg}^{2+}\right)$ in the surface waters was $95.40 \pm 5.33 \mathrm{mg} \cdot \mathrm{L}^{-1}$ (range 83-105) and $32.20 \pm 2.44 \mathrm{mg} \cdot \mathrm{L}^{-1}$ (range 27-28), respectively. Owing to the calcium content in the Chiffa river, this can be classified as calcium rich waters. In aquatic environment, calcium serves as one of the micronutrients for most of the organisms. Magnesium is often associated with calcium in all kinds of waters, but its concentration remains generally lower than the calcium [43]. Magnesium is essential for chlorophyll growth and acts as a limiting factor for the growth of phytoplankton [44]. The calcium average concentration is significantly higher $(P=0.002)$ than the desirable limit in water which is $75 \mathrm{mg} \cdot \mathrm{L}^{-1}$, the maximum permissible limit being $200 \mathrm{mg} \cdot \mathrm{L}^{-1}$. Calcium as such has no hazardous effect on human health. According to Nisbet and Verneau [45], water containing between $60 \mathrm{mg} \cdot \mathrm{L}^{-1}$ and $120 \mathrm{mg} \cdot \mathrm{L}^{-1}$ is excellent fishing waters and this is the case for the waters of the Chiffa river.

Sodium is the monovalent cation commonly present in water. This ion does not produce hardness to water. However, significantly high amounts of this ion in water create problem in its taste as well as make the water unsuitable for irrigation purpose. Sodium has also a different role in human body. It is related with the function of nervous system, membrane system, and excretory system. According to WHO [46] guideline, the maximum admissible limit is $100 \mathrm{mg} \cdot \mathrm{L}^{-1}$. In the study area, the $\mathrm{Na}^{+}$concentration in surface water ranges from 19.33 to $47.00 \mathrm{mg} \cdot \mathrm{L}^{-1}$, mean $41.93 \pm 2.38 \mathrm{mg} \cdot \mathrm{L}^{-1}$, and was all time significantly lower $(P<0.001)$ than the maximum admissible limit.

The chemical facies is dominant for cations: $\mathrm{Ca}^{2+} \gg$ $\mathrm{Na}^{+}>\mathrm{Mg}^{2+}$. This order is the natural composition of river's cations in worldwide [47].

Chlorides are important inorganic anions which contain varying concentrations in natural waters [48]. Chlorides are troublesome in irrigation water and also harmful to aquatic life [49]. High concentration of chloride is considered to be the indicators of pollution due to organic wastes of animal or industrial origin. High chloride content of water indicates organic pollution of animal origin also [28]. In this study, the chloride concentration oscillated between 35.67 and $52.00 \mathrm{mg} \cdot \mathrm{L}^{-1}$ with a mean value of $45.93 \pm 4.58 \mathrm{mg} \cdot \mathrm{L}^{-1}$. Most of our values are within the standard desirable limit prescribed by WHO. According to Zafar [50], chloride can be considered as one of the basic parameters of classifying lakes polluted by sewage into different categories. The high chloride content might be attributed to the presence of large amount of organic matter of both allochthonous and autochthonous origin [51].

Organic matter was observed to be high $\left(3.93 \mathrm{mg} \cdot \mathrm{L}^{-1}\right)$ in the month of April and minimum $\left(0.40 \mathrm{mg} \cdot \mathrm{L}^{-1}\right)$ in June with average $1.63 \pm 0.36 \mathrm{mg} \cdot \mathrm{L}^{-1}$.

Bicarbonate is the most dominant anion with an average value of $231.00 \pm 5.52 \mathrm{mg} \cdot \mathrm{L}^{-1}$, minimum $219.3 \mathrm{mg} \cdot \mathrm{L}^{-1}$ was estimated in August, and maximum $248.7 \mathrm{mg} \cdot \mathrm{L}^{-1}$ in May. $\mathrm{HCO}_{3}{ }^{-}$is derived mainly from (i) the soil zone in the subsurface environment contains $\mathrm{CO}_{2}$ with elevated pressure which in turn combines with rain water to form bicarbonate and (ii) the dissolution of carbonate and/or silicate minerals by carbonic acid. The relatively higher concentration of bicarbonate with respect to chloride suggests the intense chemical weathering taking place in the area.

The chlorophyll a concentration was ranged between 0.70 and $132.3 \mu \mathrm{g} \cdot \mathrm{L}^{-1}$, mean $46.48 \pm 22.34 \mu \mathrm{g} \cdot \mathrm{L}^{-1}$, which was in parallel with the total cell number of phytoplankton with two peaks in July and August.

The Pearson's correlation coefficient between variables is presented in Table 2.

A significant positive correlation was observed between EC and $\mathrm{Na}^{+}, \mathrm{EC}$ and $\mathrm{Ca}^{2+}, \mathrm{NO}_{3}{ }^{-}$and $\mathrm{NO}_{2}{ }^{-}, \mathrm{NO}_{3}{ }^{-}$and Org. m., $\mathrm{NO}_{3}{ }^{-}$and $\mathrm{HCO}_{3}{ }^{-}, \mathrm{NO}_{2}{ }^{-}$and Org. m., $\mathrm{NO}_{2}{ }^{-}$ and $\mathrm{HCO}_{3}{ }^{-}, \mathrm{Na}^{+}$and $\mathrm{Cl}^{-}, \mathrm{Mg}^{2+}$ and $\mathrm{HCO}_{3}{ }^{-}$. A significant negative correlation was observed between $\mathrm{T}$ and $\mathrm{NO}_{2}{ }^{-}, \mathrm{T}$ and $\mathrm{NO}_{3}{ }^{-}, T$ and Org. m., $\mathrm{NH}_{4}{ }^{+}$and $\mathrm{Na}^{+}$.

3.2. Phytoplankton. A total of 53 phytoplankton species, belonging to four classes, were recorded for the first time during the study period (Table 3). Phytoplankton is characterized by the presence of cosmopolitan species. 
TABLE 3: Phytoplankton species recorded for the first time in Chiffa river.

\begin{tabular}{|c|c|c|}
\hline Name of algal groups & Numbers of species recorded & Name of species \\
\hline Chlorophyceae & 28 & $\begin{array}{l}\text { Actinastrum hantzschii, Binuclearia tectorum, Botryococcus braunii, } \\
\text { Chlamydomonas sp., Chlorella sp., Cladophora glomerata, Closterium } \\
\text { lanceolatum, Closterium moniliferum, Closterium parvulum var } \\
\text { parvulum, Closterium sp., Cosmarium humile, Dictyosphaerium } \\
\text { pulchellum, Elakatothrix genevensis, Elakatothrix viridis, Hydrodictyon } \\
\text { reticulatum, Micractinium pusillum, Micrasterias crux, Pandorina sp., } \\
\text { Pediastrum boryanum, Rhizoclonium hieroglyphicum, Scenedesmus } \\
\text { acuminatus, Scenedesmus granulates, Spirogyra crassa, Stigeoclonium } \\
\text { aestivale, Tetraedron gracile, Tetraedron sp., Ulothrix zonata, Zygnema } \\
\text { stellinum. }\end{array}$ \\
\hline Bacillariophyceae & 15 & $\begin{array}{l}\text { Asterionella formosa, Diatoma vulgare, Diatoma sp., Gyrosigma } \\
\text { acuminatum, Melosira granulate, Melosira italica, Melosira varians, } \\
\text { Navicula radiosa, Nitzschia holsatica, Rhoicosphenia abbreviata, } \\
\text { Synedra acus, Synedra affinis, Synedra ovata } \\
\text { Synedra sp., Synedra ulna. }\end{array}$ \\
\hline Cyanophyceae & 9 & $\begin{array}{l}\text { Anabaena variabilis, Anacystis sp., Aphanizomenon flos-aquae, } \\
\text { Pseudanabaena catenata, Pseudanabaena limnetica, Raphidiopsis } \\
\text { mediterranea, Tradorma solitera, Microcystis aeruginosa, Oscillatoria } \\
\text { sancta. }\end{array}$ \\
\hline Charophyceae & 1 & Nitella flexilis. \\
\hline
\end{tabular}

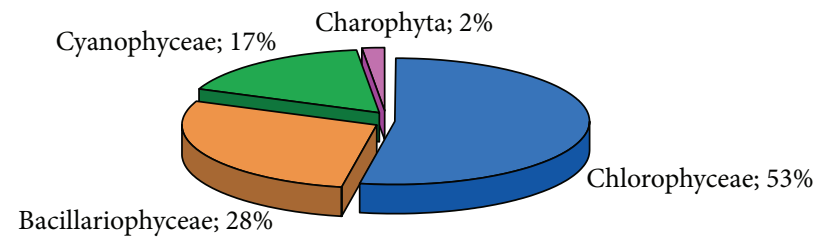

FIGURE 4: Phytoplankton species composition.

The Chlorophyceae were found to be the most diverse class which account for $53 \%$ with 22 genera, followed by Bacillariophyceae (28\%) with 8 genera, Cyanophyceae (17\%) with 8 genera, and one species of Nitella flexilis belonging to Charophyceae (2\%) (Figure 4). The species composition was found identical at the three sampling stations.

Closterium, Spirogyra, and Cladophora dominated over other Chlorophyceae members. Synedra and Melosira predominantly represented Bacillariophyceae whereas Oscillatoria was found to be a predominant group of Cyanophyceae.

Population density decreased from April to May; thereafter a sharp increase was recorded till July (Figure 5). After July again, phytoplankton density decreased sharply.

The highest phytoplankton density was observed in the month of July due to the increase in temperature (significantly correlated $P=0.043$ ) and influenced by seasonal variations in light intensity. It is a well-established fact that phytoplankton grow and multiply best during summer when the temperature is high [52-55] and longer photoperiod [56].

\section{Conclusion}

In conclusion, the various physico-chemical characteristics of Chiffa river as temperature, $\mathrm{pH}$, electric conductivity,

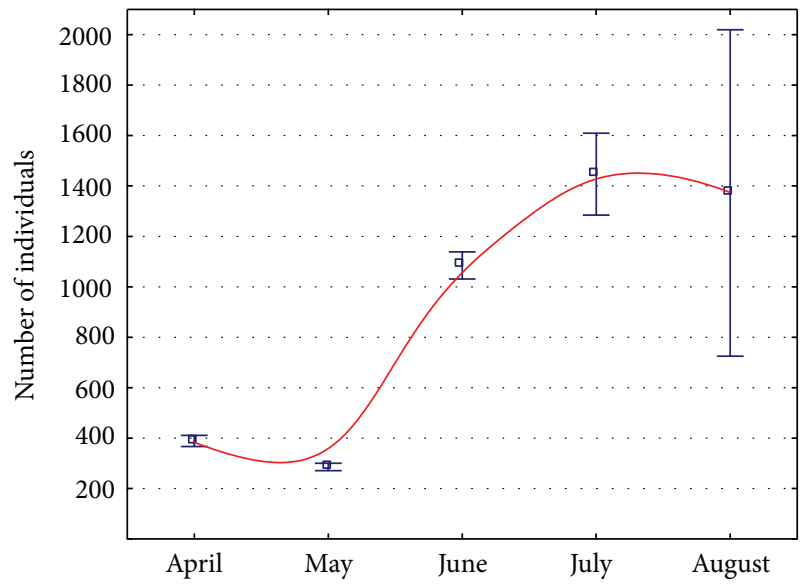

FIGURE 5: Phytoplankton density (mean \pm SE) in Chiffa river.

chloride, calcium, nitrate, and inorganic phosphorous have been compared with the trophic status as suggested by various authors (Monitoring the Water Quality of coastal waters [57] and system quality developed by Benmia and Aouabed [58]), then this river can safely be placed under the category of mesotrophic water bodies with moderate quantity of nutrients to support relatively good biota in the river. This is due to the fact that there is few municipal sewage and industrial waste discharge to the river. Though it receives moderate amount of pollution from anthropogenic activities by local village people at present, but if the similar conditions persist in the time, Chiffa river may soon become mesotrophic to eutrophic water body. However, dredging sand activities should be discouraged in the study site in order to enhance its phytoplankton biodiversity. Regular monitoring using an 
optimal monitoring network at a suitable frequency is recommended to detect any unacceptable variability of pollutants and adopt appropriate remedial measures.

The physico-chemical and the phytoplankton data obtained in this river could be used as a baseline and reference point when assessing further changes caused by nature or man in this river, since there has not been published information or data on this river.

\section{References}

[1] C. E. Williamson, W. Dodds, T. K. Kratz, and M. A. Palmer, "Lakes and streams as sentinels of environmental change in terrestrial and atmospheric processes," Frontiers in Ecology and the Environment, vol. 6, no. 5, pp. 247-254, 2008.

[2] U. K. Ekwenye and C. A. Oji, "Quality of water from boreholes in Umualia, Nigeria," Environment and Ecology, vol. 26, pp. 543545, 2008.

[3] D. K. Singh and I. Singh, "Interrelationship of certain physicochemical parameters with plankton community of Motipur Oxbow lakes (Muzaffarpur, Bihar)," Environment and Ecology, vol. 26, no. 2, pp. 800-803, 2008.

[4] R. Mushini Venkata Subba, R. Vaddi Dhilleswara, and S. A. A. Bethapudi, "Assessment of quality of drinking water at Srikurmam in Srikakulam district, Andhra Pradesh, India," International Research Journal of Environment Sciences, vol. 1, no. 2, pp. 13-20, 2012.

[5] P. Jayakumar, N. Jothivel, A. Thimmappaand, and V. I. Paul, "Physico-chemical characterization of a lentic water body from Tamil Nadu with special reference to its pollution status," The Ecoscan, vol. 3, no. 1-2, pp. 59-64, 2009.

[6] B. Kim, J. H. Park, G. Hwang, M. S. Jun, and K. Choi, "Eutrophication of reservoirs in South Korea," Limnology, vol. 2, no. 3, pp. 223-229, 2001.

[7] O. I. Vandysh, "Zooplankton as an indicator of the state of lake ecosystems polluted with mining wastewater in the Kola Peninsula," Russian Journal of Ecology, vol. 35, no. 2, pp. 110-116, 2004.

[8] L. Gauthier-Lievre, Recherches sur la Flore des Eaux Continentales de l'Afrique du Nord, Bulletin de la Société Histoire Naturelle d'Afrique Noire, Mémoire Hors-Série, 1931.

[9] R. Baudrimont, Recherches sur les diatomées des eaux continentales de l'Algérie [thesis], University of Bordeaux, Talence, France, 1973.

[10] M. Bensouilah, R. Chaibi, and C. Bouallag, "Production aquacole et peuplement en cyanophycées d'un plan d'eau saumâtre (la lagune El Mellah) de la région extrême nord est Algérienne," Bulletin de L'INSTM, no. 8, pp. 29-32, 2003.

[11] H. Nasri, N. Bouaicha, N. Loucif, A. B. Nasri, and M. Bensouilah, "Impact of the toxics cyanobacteria in freshwater dam of the east Algeria," in Proceedings of the 7th International Water Technology Conference (IWTC '03), vol. 1, pp. 207-227, Cairo, Egypt, June 2003.

[12] A. B. Nasri, N. Bouaïcha, and J. Fastner, "First Report of a Microcystin-Containing Bloom of the Cyanobacteria Microcystis spp. in Lake Oubeira, Eastern Algeria," Archives of Environmental Contamination and Toxicology, vol. 46, no. 2, pp. 197-202, 2004.

[13] H. Nasri, N. Bouaïcha, and M. K. Harche, "A new morphospecies of Microcystis sp. forming bloom in the cheffia dam (Algeria): seasonal variation of microcystin concentrations in raw water and their removal in a full-scale treatment plant," Environmental Toxicology, vol. 22, no. 4, pp. 347-356, 2007.

[14] H. Nasri, N. Bouaïcha, and M. Kaid Harche, "Variation saisonnière des toxines de cyanobactéries de type microcystine dans le barrage cheffia et leur élimination dans la station chaiba," Algerian Journal of Technology, vol. 1, pp. 237-255, 2008.

[15] B. Soumati, H. Nasri, A. Meddour, S. Kadri, and N. Loucif, "Space-time dynamics and parameters of growth of toxic cyanobacteria in freshwaters in Cheffia dam (north-east of Algeria)," in Proceedings of the 9th International Water Technology Conference (IWTC '09), pp. 755-764, Sharm El-Sheikh, Egypt, 2005.

[16] M. Souissi, R. Chaibi, M. Melizi, and M. Bensouilah, "Les Cyanobactéries d'un plan d'eau douce (lac Oubeira, EL-KALA), inventaire et répartition spatiale," Science \& Technology, vol. 22, pp. 38-42, 2004.

[17] S. Amri, Z. Branes, and B. Oudra, "Inventaire des cyanobactéries potentiellement toxiques dans la tourbière du lac noir "parc national d'El-Kala" (Algérie)," Revue de Microbiologie Industrielle Sanitaire et Environnementale, vol. 4, no. 1, pp. 4968, 2010.

[18] A. Ouartsi, A. Saoudi, and D. Chekireb, "Etude des efflorescences toxiques à cyanobactéries dans le barrage Mexa, Algérie," Revue de Microbiologie Industrielle Sanitaire et Environnementale, vol. 5, no. 1, pp. 81-100, 2011.

[19] M. S. Al-Asadi, P. Randerson, and K. Benson-Evans, "Phytoplankton population dynamics in three West Algerian rivers. The River Cheliff and its tributary the river Mina," Marina Mesopotamica, vol. 1, no. 1, pp. 48-472, 2006.

[20] Z. Branes, D. Sargos, M. Ounissi, and M. Amblard, "Dynamique spécifique et biomasse du phytoplancton du lac Oubeira (Algérie)," European Journal of Scientific Research, vol. 16, no. 3, pp. 477-489, 2007.

[21] N. Chaï, A. H. Alfarhan, K. A. S. Al-Rasheid, and B. Samraoui, "Environmental determinants of diatom assemblages along a North African wadi, the Kebir-East, North-East Algeria," Journal of Limnology, vol. 70, no. 1, pp. 33-40, 2011.

[22] M. S. Hamaidi, F. Hamaidi, A. Zoubiri, F. Benouaklil, and Y. Dhan, "Etude de la dynamique des populations phytoplanctoniques et résultats préliminaires sur les blooms toxiques à Cyanobactéries dans le barrage de Ghrib (Ain Defla-Algérie)," European Journal of Scientific Research, vol. 32, no. 3, pp. 369380, 2009.

[23] G. L. Niox, Géographie Militaire VI, Algérie et Tunisie, Baudoin et Cie, 1890.

[24] M. R. Khouli and L. Djabri, "Impact of use of agricultural inputs on the quality of groundwater case of Mitidja plain (Algeria)," Geographia Technica, vol. 11, no. 2, pp. 35-44, 2011.

[25] APHA, Standard Methods for the Examination of Water and Wastewater, American Public Health Association, Washington, DC, USA, 18th edition, 1998.

[26] J. Rodier, L'Analyse de l'Eau: Eaux Naturelles, Eaux Résiduaires, Eau de Mer, Dunod, Paris, France, 7th edition, 1984.

[27] H. L. Golterman, R. S. Clymo, and M. A. M. Ohmstad, Methods for Physical and Chemical Analysis of Freshwaters, Blackwell Scientific Publication, Oxford, UK, 1978.

[28] P. Bourrelly, Les Algues D'eau Douce. Initiation à La Systématique. Tome I: Les Algues Vertes, Boubée et Cie, Paris, France, 1966.

[29] P. Compère, "Algues de la région du lac Tchad. II: cyanophycées," Cahiers ORSTOM Série Hydrobiologie, vol. 8, no. 3-4, pp. 165-198, 1974. 
[30] P. Compère, "Algues de la région du lac Tchad. IV: diatomophycées," Cahiers ORSTOM Série Hydrobiologie, vol. 9, no. 4, pp. 203-290, 1975.

[31] P. Compère, "Algues de la région du lac Tchad. VII: chlorophycophytes (3ème partie: desmidiées)," CCahiers ORSTOM Série Hydrobiologie, vol. 11, no. 2, pp. 135-164, 1977.

[32] K. Anagnostidis and J. Komárek, "Modern approach to the classification system of cyanophytes. 3: oscillatoriales. Algological Studies," Archiv für Hydrobiologie, no. 50-53, pp. 327-472, 1988.

[33] F. I. Opute, "Contribution to the knowledge of algae of Nigeria. I. Desmids from the Warri/Forcados Estuaries. Part II. The elongate baculiform desmids," Journal of Limnology, vol. 59, no. 2, pp. 131-155, 2000.

[34] K. Krammer and H. Lange-Bertalot, Bacillariophyceae: 3. Teil: Centrales, Fragilariaceae, Eunotiaceae (Süwasserflora von Mitteleuropa), Gustav Fisher, 1991.

[35] A. Nait Merzoug and H. Merazig, "Water pollution of oued medjerda in Algerian souk ahras region," in Water Quality Monitoring and Assessment, pp. 527-540, 2012.

[36] APHA, Standard Methods for Examination of Water and Wastewater, American Public Health Association, Washington, DC, USA, 19th edition, 1995.

[37] J. P. Larpent and M. Larpent-Gourgand, Mémento Technique de Microbiologie, Lavoisier Tech et Doc, 3rd edition, 1997.

[38] L. R. Bhatt, P. Lacoul, H. D. Lekhak, and P. K. Jha, "Physicochemical characteristics and phytoplanktons of Taudaha lake, Kathmandu," Pollution Research, vol. 18, no. 4, pp. 353-358, 1999.

[39] WHO, Guidelines for Drinking-Water Quality Vol. 1. Recommandations, World Health Organization, Geneva, Switzerland, 3rd edition, 2004.

[40] "Législation: eau-eaux de surface/normes de qualité," Journal Officiel de la République Algérienne, no. 46, 1993.

[41] U.S. Environmental Protection Agency, "Quality criteria for water," Tech. Rep. EPA-440/9-76-023, Environmental Protection Agency, Washington, D.C, USA, 1976.

[42] W. Ohle, "Chemische and physikalische untersuchunger norddentscher seen," Archiv für Hydrobiologie, vol. 26, pp. 386-464, 1934.

[43] R. Venkatasubramani and T. Meenambal, "Study on subsurface water quality in Mettupalayam taluk of Coimbatore district, Tamil Nadu," Nature Environment and Pollution Technology, vol. 6, no. 2, pp. 307-310, 2007.

[44] A. Dagaonkar and D. N. Saksena, "Physico-chemical and Biological characterization of a temple tank, Kaila Sagar, Gwalior, Madhya Pradesh," Hydrobiological Journal, vol. 8, no. 1, pp. 1119, 1992.

[45] M. Nisbet and J. Verneau, "Composantes chimiques des eaux courantes," Annales de Limnologie, vol. 6, no. 2, pp. 161-190, 1970.

[46] WHO, Guidelines for Drinking Water Quality Vol. 1. Recommandations, World Health Organization, Geneva, Switzerland, 3rd edition, 2006.

[47] K. Slim, Z. Saad, O. El-Samad, and V. Kazpard, "Caractérisation chimique et algologique des eaux superficielles de la rivière Oronte (Liban) dans un climat semi-aride," Sécheresse, vol. 16, no. 2, pp. 131-135, 2005.

[48] M. Makhoukh, M. Sbaa, A. Berrahou, and M. Van Clooster, "Contribution à l'étude physico-chimique des eaux superficielles de l'Oued Moulouya (Maroc oriental)," Larhyss Journal, no. 9, pp. 149-169, 2011.

[49] S. Rajkumar, P. Velmurugan, K. Shanthi, P. M. Ayyasamy, and P. Lakshmanaperumalasamy, "Water quality of Kodaikanal lake," in Tamilnadu in Relation to Physico-Chemical and Bacteriological Characteristics, pp. 339-346, Capital Publishing Company, Lake, 2004.

[50] A. R. Zafar, "On the ecology of algae in certain fish ponds of Hyderabad, India," Hydrobiologia, vol. 24, no. 3-4, pp. 556-566, 1964.

[51] A. K. Pandit, Freshwater Ecosystems of the Himalaya, Parthenon Publishing, London, UK, 1999.

[52] T. L. Richardson, C. E. Gibson, and S. I. Heaney, “Temperature, growth and seasonal succession of phytoplankton in Lake Baikal, Siberia," Freshwater Biology, vol. 44, no. 3, pp. 431-440, 2000.

[53] I. Izaguirre, I. O’Farrell, and G. Tell, "Variation in phytoplankton composition and limnological features in a water-water ecotone of the Lower Paraná Basin (Argentina)," Freshwater Biology, vol. 46, no. 1, pp. 63-74, 2001.

[54] F. Farahani, H. Korehi, S. Mollakarami, S. Skandari, S. G. G. Zaferani, and Z. M. C. Shashm, "Phytoplankton diversity and nutrients at the Jajerood river in Iran," Pakistan Journal of Biological Sciences, vol. 9, no. 9, pp. 1787-1790, 2006.

[55] M. M. R. Chowdhury, M. R. K. Mondol, and C. Sarker, "Seasonal variation in plankton population of Borobila beel in Rangpur district," University Journal of Zoology, Rajshahi University, vol. 26, pp. 49-454, 2007.

[56] A. K. Tyor and C. Deepti, "Survey and study of phytoplankton ecology in Sukhna lake, Chandigarh, (India)," International Journal of Applied Biology and Pharmaceutical Technology, vol. 3, no. 2, pp. 229-238, 2012.

[57] "SEQ Littoral. Système de classification pour l'évaluation de la qualité des eaux littorales: grilles d'aptitude aux usages et à la biologie," Contrat MEDD/Ifremer no 031-01, 2002.

[58] M. Benmia and A. Aouabed, "Contribution à l'élaboration d'un modèle de carte de qualité: cas de la région centre de l'Algérie," in La Première Journée Scientifique sur le Traitement et la Réutilisation des Eaux, pp. 1-10, 2007. 

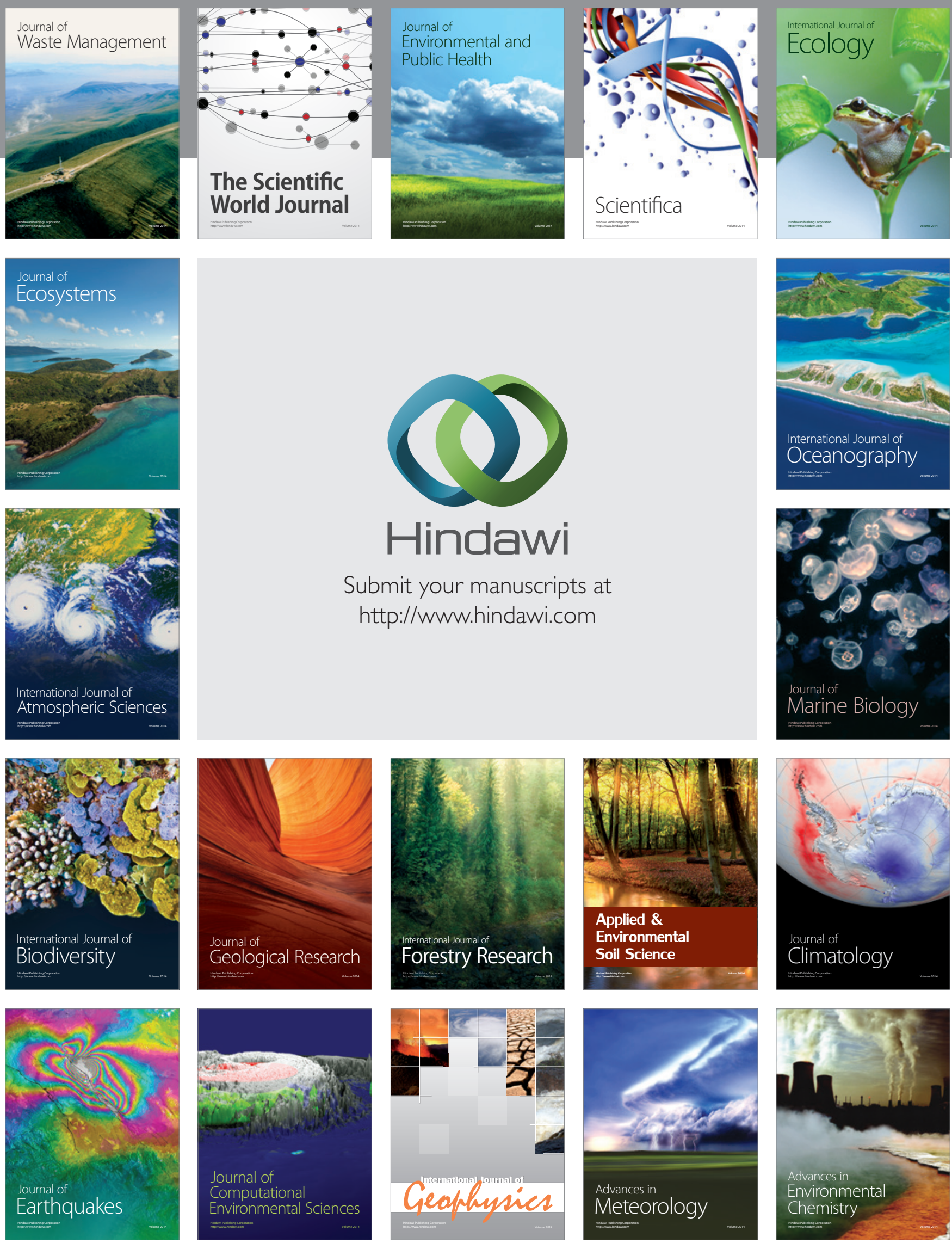